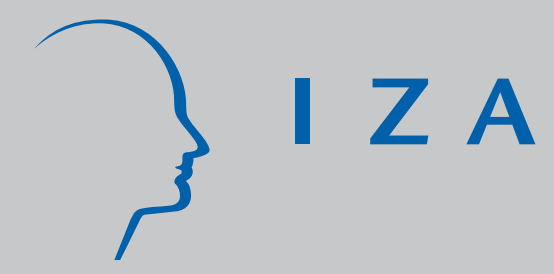

IZA DP No. 2942

Precautionary Savings by Natives and Immigrants in Germany

Matloob Piracha

Yu Zhu

July 2007 


\title{
Precautionary Savings by Natives and Immigrants in Germany
}

\author{
Matloob Piracha \\ University of Kent \\ and IZA
}

Yu Zhu

University of Kent

\author{
Discussion Paper No. 2942 \\ July 2007
}

\author{
IZA \\ P.O. Box 7240 \\ 53072 Bonn \\ Germany \\ Phone: +49-228-3894-0 \\ Fax: +49-228-3894-180 \\ E-mail: iza@iza.org
}

Any opinions expressed here are those of the author(s) and not those of the institute. Research disseminated by IZA may include views on policy, but the institute itself takes no institutional policy positions.

The Institute for the Study of Labor (IZA) in Bonn is a local and virtual international research center and a place of communication between science, politics and business. IZA is an independent nonprofit company supported by Deutsche Post World Net. The center is associated with the University of Bonn and offers a stimulating research environment through its research networks, research support, and visitors and doctoral programs. IZA engages in (i) original and internationally competitive research in all fields of labor economics, (ii) development of policy concepts, and (iii) dissemination of research results and concepts to the interested public.

IZA Discussion Papers often represent preliminary work and are circulated to encourage discussion. Citation of such a paper should account for its provisional character. A revised version may be available directly from the author. 


\begin{abstract}

\section{Precautionary Savings by Natives and Immigrants in Germany}

This paper analyses the savings behaviour of natives and immigrants in Germany. It is argued that uncertainty about future income and legal status (in case of immigrants) is a key component in the determination of the level of precautionary savings. Using the German Socio-economic Panel data it is shown that, although immigrants have lower levels of savings and are less likely to have regular savings than natives, the gap is significantly narrowed once we take loan repayments and remittances into account. Moreover, we find that marginal propensity to save for immigrants is about $40 \%$ higher than that for natives. We then exploit a natural experiment arising from a change in nationality law in Germany in 2000 to estimate the importance of precautionary savings. Using a difference-in-differences approach, we find that the easing of the requirements for naturalization has caused significant reductions of savings and remittances for immigrants as a whole, in the magnitude of $13 \%$ and $29 \%$ respectively, comparing to the pre-reform period. Our parametric specification shows that the introduction of the new nationality law reduces the gap between natives and immigrants in marginal propensity to save by $40 \%$ to $65 \%$, depending on the measure of savings used. These findings suggest that much of the differences in terms of the savings behaviour between natives and immigrants are driven by the precautionary savings arising from the uncertainties about future income and legal status rather than cultural differences.
\end{abstract}

JEL Classification: D80, E21, F22

Keywords: migration, remittances, savings, uncertainty

Corresponding author:

Matloob Piracha

Department of Economics

University of Kent

Canterbury, Kent CT2 7NP

United Kingdom

E-mail: M.E.Piracha@ukc.ac.uk

\footnotetext{
*We would like to thank Ira Gang, Robert E.B. Lucas and participants at the XXI Annual Conference of the European Society for Population Economics, Chicago, for helpful comments.
} 


\section{Introduction}

Most of the research on migration has focused on the labour market performance of immigrants, hence ignoring their role in capital markets, particularly their savings behaviour. Although recent literature has filled this gap somewhat, further analysis is needed to systematically analyse the differences between levels of precautionary savings of natives and immigrants, especially since savings is an important determinant of the assimilation process in the host country.

Recently several papers have contributed to the general topic of migrants' savings behaviour. Galor and Stark (1990) and Dustmann (1997) consider the link between return intentions of migration and their savings behaviour. Using overlapping generations model, Galor and Stark show that the higher the probability of emigration from the host country higher is the level of savings. They argue that since migrants have high possibility of emigrating back to the source country, compared to natives, immigrants save more than natives. ${ }^{1}$

Dustmann (1997) endogenises migrants' return-intention with their savings decision. More precisely, he links (precautionary) savings and return decisions with the level of uncertainty about future income stream. He shows that if labour markets in the home and host regions are correlated then immigrants will save more than the natives as they are subject to more income risk in the host country than are the natives. However, in the absence of correlation of economic conditions between the two countries, risk diversification favours immigrants as they are highly likely to emigrate back to their

\footnotetext{
${ }^{1}$ Other arguments have also been explored for the difference in savings rate between natives and immigrants. There might be cultural or socioeconomic reasons which determine the level of savings, though this has been rejected by Shamsuddin and DeVortez (1998). Skill differences could also be responsible as it has an effect on the economic performance of immigrants (see Chiswick 1978 and Borjas 1987) which could affect their savings behaviour.
} 
home country in case of worsening labour market conditions in the host country. In such a circumstance, immigrants will save less compared to the natives.

Amuedo-Dorantes and Pozo (2002) use the 1979 Youth Cohort of the National Longitudinal Surveys (NLSY79) to compare the precautionary savings and wealth patterns of immigrants and natives. They find that immigrants on average accumulate less wealth, i.e., carry out lower precautionary savings in the host country, compared to natives. This finding is consistent with earlier results of Carroll, Rhee and Rhee (1994) for Canada, Merkle and Zimmermann (1993) for Germany and also partially support the theoretical results of Dustmann (1997).

In a related paper, Amuedo-Dorantes and Pozo (2006) analyse the motives for remittances by the migrants. They argue that remittances are transferred to the home country for multiple reasons: to help family members (altruism), to purchase familyprovided insurance (informal agreement for reciprocal help in case of economic hardship faced by the migrant) and self-insurance (precautionary savings). They call the latter two the "insurance" motive and test this by correlating host variables with flows of remittances. More precisely, they determine the correlation between risk and uncertainty level in the host country with level of remittances, i.e., the level of insurance they purchase.

Finally, a recent paper by Bauer and Sinning (2006) studies the savings behaviour of temporary and permanent migrants in Germany and compares that to those of the natives. Although their scope is a bit wider than ours, the main concept of their paper and ours is similar in nature. However, our paper differs from theirs in two significant ways. 
Firstly, they ex ante impose a decision rule regarding the type of migration, temporary or permanent, whereas we follow Dustmann (1997) by making the decision process endogenous in nature. A large number of individuals initially migrate with a different motive but change their mind once they arrive, and spend time, in the host country. Therefore making the migration decision endogenous is crucial to this type of analysis.

Secondly, and in relation to the above point, we explicitly introduce uncertainty to study the savings behaviour of natives and immigrants. Within this framework then, there are two different scenarios. On the one hand it could be argued that immigrants save more than the natives as there is a higher level of uncertainty regarding migrant's employment status (because perhaps of their skill level or residency status in the country) and thus there is higher risk of lower earnings in the future. Under this condition, immigrants are likely to save more than the natives. However, on the other hand, immigrants have the option to diversify risk by taking employment in their home country when conditions in the host country get worse. In this case they are likely to have lower level of savings compared to the natives.

In terms of modelling the approach discussed above, we believe that the two aspects of savings discussed in two separate papers by Amuedo-Dorantes and Pozo (2002, 2006) could be analysed within the same framework to make a proper comparison between natives and immigrants since for immigrants savings behaviour is related to the remittance behaviour as for them part of the savings takes place outside the host country. More precisely we assume agents to be uncertain about their future stream of income and 
maximise their utility over 2 periods with two possible states of the world in period two: either "good" (high income, which is assumed in period 1) or "bad" (low income).

Using the German Socio-Economic Panel data we find that, once remittances are taken into account, immigrants tend to save more than the natives. However, in order to capture the impact of uncertainty on the savings (including remittance) behaviour of immigrants, we exploit the natural experiment arising from a change in nationality law in Germany in 2000. We find that the easing of the requirements for naturalization has caused significant reductions of savings and remittances for immigrants as a whole, which is consistent with our risk story. In other words, with a fall in the uncertainty level in the host country a migrant tends to behave more like a native which shows a positive trend towards assimilation.

The rest of the paper is organised as follows. Section 2 outlines a brief theoretical model to set out the foundation for the estimations of the model. Section 3 discusses the data while section 4 presents the empirical analysis. The last section concludes the paper.

\section{A Brief Theoretical Model}

Following Amuedo-Dorantes and Pozo (2006), we consider a two-period model in which the households know with certainty their income in the first period but there is uncertainty about the income in the second period which consists of a "good" state or a "bad" state. More precisely, income level in the second period, in the good state, is $Y^{L}$ (low) with probability $\mu$ and $Y^{H}$ (high), in the bad state, with probability $(1-\mu)$. In the first period the income level is assumed to be $Y^{H}$ with certainty. 
Households derive their utility from consumption $C_{1}$ in the first period and a discounted consumption level $C_{2}$ in the second period.

$$
U=\ln C_{1}+\delta \ln C_{2}
$$

where $\delta$ is the discount factor.

As in the simple two-period model, consumption in the first period is constrained by the savings made in that period for use in the second period,

$$
C_{1} \leq Y^{H}-S
$$

In period 2, the household is faced with two possibilities. Either the good state will prevail with probability $(1-\mu)$ or the household will face the bad state with probability $\mu$, then

$$
C_{2} \leq \mu\left[Y^{L}+S(1+r)\right]+(1-\mu)\left[Y^{H}+S(1+r)\right]
$$

where $r$ is the interest rate.

The households choose the level of savings to maximise their utility subject to the two constraints. The first order condition for this maximisation problem gives us the intertemporal consumption choices.

$$
\begin{aligned}
& U^{S}=\frac{\partial U}{\partial S}=-\delta C_{1}(1+r)+C_{2}=0 \\
& \Rightarrow C_{2}=\delta C_{1}(1+r)
\end{aligned}
$$

Our objective in this paper is to analyse the role of uncertainty on the savings behaviour of households. In particular we want to determine whether non-natives save 
more or less as a precautionary motive compared to the natives. A priori we have two competing views on migrants' savings behaviour. One, as mentioned earlier, is that migrants are subject to more income risk in the host country than are the natives therefore will tend to save more. However, on the other hand migrants are more likely to diversify risk as they could always emigrate back to their home country if economic conditions in the host country were unfavourable. In this case migrants are likely to save less than the natives. The two conditions in our framework could be shown below.

Using the implicit function theorem we can derive the comparative results.

$$
\frac{\partial S}{\partial \mu}=-\frac{\partial U^{S} / \partial \mu}{\partial U^{S} / \partial S}=-\frac{\left(Y^{L}-Y^{H}\right)}{(1+\delta)(1+r)}>0
$$

This result suggests that an increase in the probability of the poor state increases the savings rate. This is consistent with the permanent income hypothesis as it states that an individual will decrease consumption in the good state (in the first period) and will increase saving to smooth out consumption over the lifetime.

$$
\begin{gathered}
\frac{\partial S}{\partial Y_{H}}=-\frac{\partial U^{S} / \partial Y_{H}}{\partial U^{S} / \partial S}=-\frac{(1-\mu)-\delta(1+r)}{(1+\delta)(1+r)}>0 \\
\frac{\partial S}{\partial Y_{L}}=-\frac{\partial U^{S} / \partial Y_{L}}{\partial U^{S} / \partial S}=-\frac{\mu}{(1+\delta)(1+r)}<0
\end{gathered}
$$

The sign for eq (6) is satisfied if the individual's discount rate of future consumption $\delta>\frac{1-\mu}{1+r}$; a very small discount rate is required to trigger savings in the presence of high uncertainty level of future income. Equations (6) and (7) together imply that 
$\frac{\partial S}{\partial\left(Y^{H}-Y^{L}\right)}>0$ which means a higher dispersion between the good and bad state results in higher level of savings. This is then consistent with consumption smoothing as well as with our story of saving for the future in the presence of uncertainty about the state of the world in the second period. In the rest of the paper we conduct an empirical analysis of this setup. More precisely, we will determine the effect of uncertainty on the savings behaviour of immigrants (and compare it to that of natives) due to a change in their legal (residency) status in Germany.

\section{Data}

We use the German Socio-Economic Panel (GSOEP) data which is a representative micro data on individuals and families in Germany collected annually since 1984. The sample consists of households with a head aged between 16 and 65 during 1998-2005 inclusive, i.e. waves 15 through $22^{2}$. Since one of the main focus points, as mentioned in the Introduction, is the analysis of the impact of new nationality law (change in the legal residency status of immigrants) which came into effect in January 2000 (see Appendix A), we exclude the "Innovation Sample” and the "High Income Sample”, both of which were added to the main sample after 2000 . As only $1 \%$ of all immigrants live in East Germany at any time, we also drop East Germany from our sample.

\footnotetext{
${ }^{2} 2005$ is the latest year available. The year 1998 was chosen as the beginning of the sample period because this enables the inclusion of both the "Immigrants Sample" starting in 1994/95 and the "Refreshment Sample” starting in 1998.
} 
We distinguish between natives and immigrants according to the country of birth and nationality. For the purpose of our analysis, a native (German) is defined as someone who was born in Germany and holds German citizenship ${ }^{3}$. In contrast, an immigrant (non-native) is someone who was not born in Germany, regardless of nationality. Within the group of immigrants, we can further differentiate between naturalized immigrants and foreigners according to the current nationality ${ }^{4}$. Our final sample consists of 5551 distinct households, of which 1297 are non-natives. The median spells are 7 waves for natives and 6 for immigrants.

The literature suggests that nationality and country of origin matter for people's saving and remittance behaviour. In particular, these factors are expected to affect people’s precautionary savings. For instance, immigrants might have a higher marginal propensity to save (MPS) compared to the natives because they face higher employment/income uncertainties for various reasons, such as restrictions imposed by the legal and welfare system or discrimination in the labour market. On the other hand, an alternative explanation to differential in the MPS is the unobserved heterogeneity (for “culture effects”, see e.g. Carroll, Rhee and Rhee 1994) across natives and immigrants. The discrimination between these two competing hypotheses is not only of academic interest, it also carries important policy implications: if differences in preferences or tastes (or culture in general) are responsible for the variation in the marginal propensity to save across natives and immigrants, then one would expect to see a convergence in the savings and consumption behaviour through the process of assimilation which is long-

\footnotetext{
${ }^{3}$ GSOEP does not ask respondents about the country of births of their parents.

${ }^{4}$ There are 183 distinct individuals who were born in Germany but do not have German citizenship in our sample. These are presumably second-generation immigrants who form an interesting group in its own right. However, we feel that the sample size is too small to generate estimates with any precision and therefore decide to leave them out for the current paper.
} 
term in nature. In contrast, if the difference in MPS across natives and immigrants is largely driven by differentials in uncertainties (i.e. precautionary savings motive), then legal reforms that reduce uncertainties might lead to sizeable changes in behaviour over the short-term. Therefore, the real challenge from an econometric point of view is to find an exogenous variation that will allow us to disentangle the effect of unobservables from that of different degrees of uncertainties faced by these two distinct groups.

The recent reform of the nationality law in Germany offers us such a natural experiment. The 2000 citizenship legislation replaced the previous one which was solely based on the principle of descent (jus anguinis), dating back to the imperial period of 1913, with the introduction of the country of birth (jus soli) principle in the citizenship law and the easing of the requirements for naturalization. This reform was only made possible after the Red-Green coalition led by Gerhard Schröder came to power in 1998, and therefore was largely unanticipated at the time $e^{5}$. The change was also radical. For instance, the qualifying period was reduced from a minimum of 15 years to 8 years. Figure 1 shows that the proportion of non-natives acquiring German citizenship has steadily increased by more than a quarter, from $33 \%$ to $42 \%$, over our sample period. This pattern is consistent with aggregate statistics from official source.

\footnotetext{
${ }^{5}$ This implies that the choice of 1998 as the start of our sample period should work against us in finding a significant impact of the law change if anything.
} 
Figure 1: Acquisition of German Citizenship by Non-natives, 1998-2005

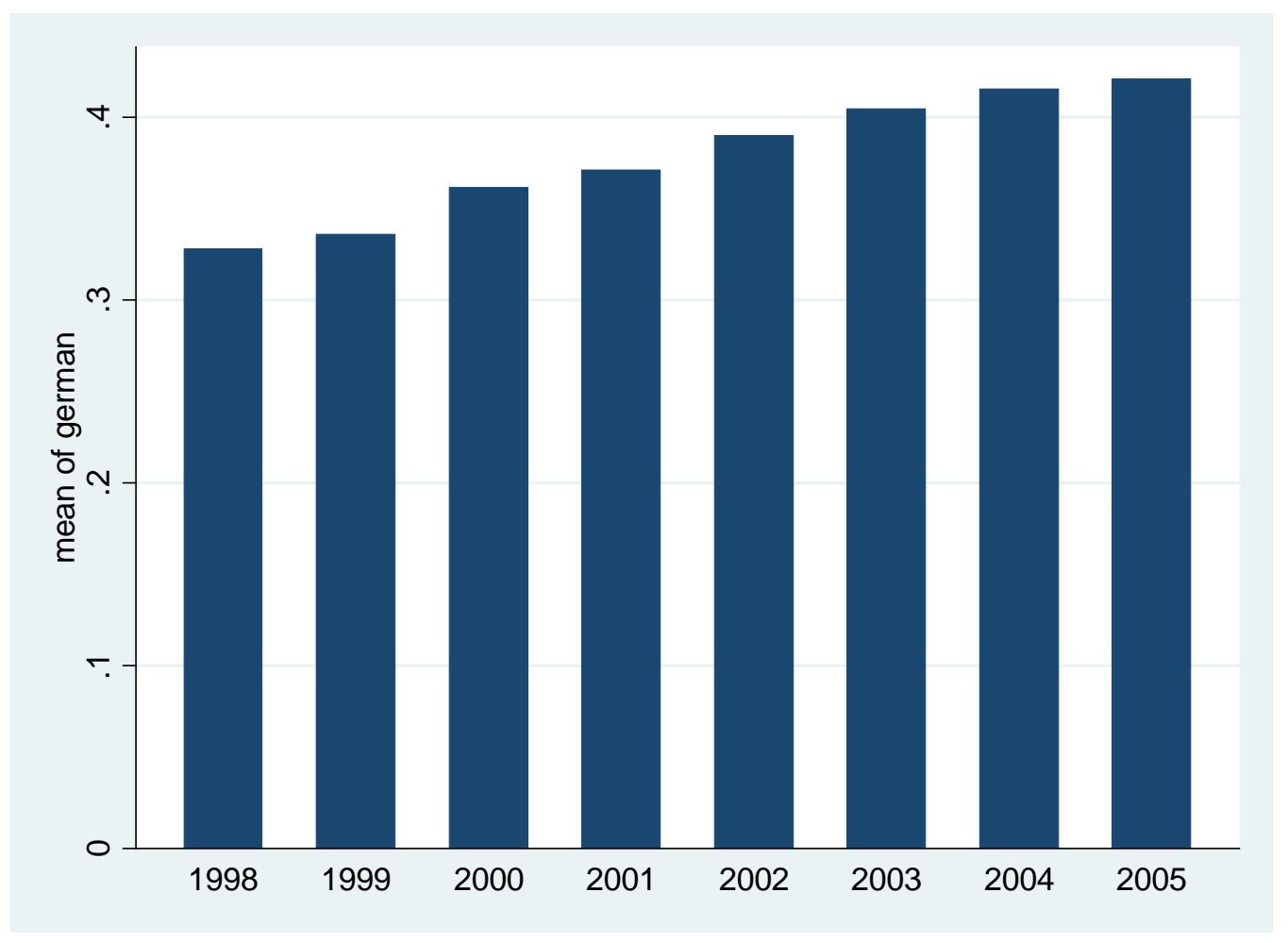

The outcome variable we focus on in this paper is "savings". Three alternative measures are used throughout the paper, ranging from the narrowest to the broadest:

1) saving0: usual amount of money left over at the end of the month that the household can save for larger purchases, emergency expenses or to acquire wealth;

2) saving1 (saving0 + loan repayments): this also includes the amount of income for paying back loans which the household took out for major purchases of other expenses; 
saving2 (saving1 + remittances): this adds further payments or support by all household members to parents, children, (ex) spouse, and other persons related (or not) who live abroad. To the extent that all remittances are "insurance" related, this definition is fully justified. However, if parts of the remittances are motivated by altruism, then this definition might be regarded as an upper bound.

Figure 2 shows the mean levels of savings, loan repayments and remittances over time by legal status. It is obvious that natives save more on average than immigrants. This is not surprising as we do not control for any other factors, the most important of which is the household income. What is really striking is change in savings behaviour among immigrants that seems to take place around 2002-2003. Comparing to natives who have demonstrated remarkable stability over the sample period (with perhaps the exception of loan repayments which trended upwards), both savings and remittances have experienced a dramatic drop while loan repayments have increased post 2002 for the subsample of immigrants. 
Figure 2: Mean Savings, Loan Repayments and Remittances over Time by Legal Status

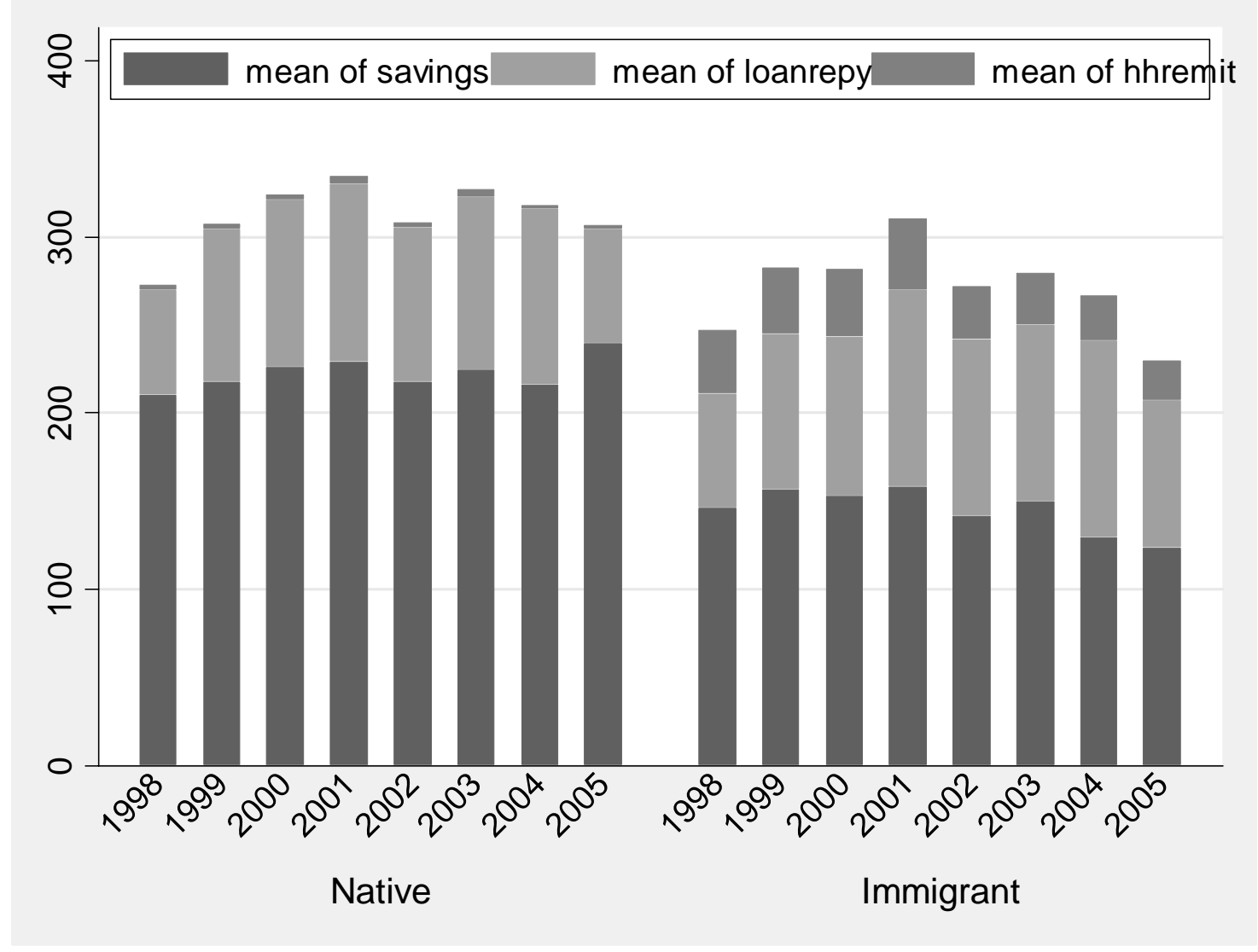

Table 1 gives the summary statistics of the key variables for natives and immigrants separately. As we have mentioned before, almost $40 \%$ of immigrants in our sample period do not have German nationality, hence are classified as foreigners. Natives save $€ 222$ per month on average, more than $50 \%$ higher than the mean savings by immigrants. This "savings gap" is reduced to less than $30 \%$ if we consider loan repayments as savings. Once we take remittances into account, the gap is further reduced to less than $15 \%$. 
Although theoretically saving can be negative, it is often reported as a variable left-censored at zero in household surveys such as the GSOEP. Policymakers are interested in finding out the number and share of savers as well as the level of savings. So we also report the percentage of savers by different definitions in Table 1 . It turns out that natives not only save more on average, but are also more likely to have positive savings. Over $60 \%$ of natives save on a regular basis, a figure which is about $35 \%$ higher than the $45 \%$ for immigrants. However, as with the levels of savings, this gap in headcounts is also significantly reduced when we move to broader definition of savings. For instance, once we take into account both loan repayments and remittances, this gap is reduced to less than $10 \%$.

Comparing to natives, immigrant heads of households are slightly older (45.2 vs 43.5 years old) and much less likely to be female ( $25.1 \%$ vs $37.8 \%)$. They receive 1.4 years less schooling but are more likely to be married. Over a quarter of immigrants are of Turkish origin while about one in six immigrants is from former Yugoslavia. They are also less likely to be in work, and more than twice as likely to be unemployed (omitted category being inactivity) and more likely to be receiving social assistance. They are only half as likely to own their houses and apartments. Finally, immigrant families also tend to be larger and have more dependent children.

To sum up, immigrants seem to fare worse in terms of virtually all socioeconomic indicators comparing to natives. However, this is not surprising given their relatively more disadvantaged background and the constraints imposed by their legal status. 
Table 1: Summary statistics

\begin{tabular}{|l|c|c|}
\hline & Natives & Immigrants \\
\hline Foreigner & - & 0.626 \\
\hline Saving0 (€/month) & 222.2 & 145.6 \\
\hline Prop. with positive saving0 (\%) & 60.8 & $45.2 \%$ \\
\hline Saving1 (€/month) & 308.5 & 238.5 \\
\hline Prop. with positive saving1(\%) & 71.9 & 60.9 \\
\hline Saving2 (€/month) & 311.8 & 271.7 \\
\hline Prop. with positive saving2(\%) & 72.2 & 65.8 \\
\hline Age & 43.5 & 45.2 \\
\hline Female (\%) & 37.8 & 25.1 \\
\hline Married (\%) & 57.7 & 75.5 \\
\hline Years of Education & 12.2 & 10.8 \\
\hline Turkish (\%) & - & 26.9 \\
\hline Former Yugoslavia (\%) & - & 15.5 \\
\hline Employed (\%) & 75.8 & 68.9 \\
\hline Unemployed (\%) & 4.5 & 11.3 \\
\hline Receiving Social Assistance (\%) & 2.7 & 4.8 \\
\hline Own House (\%) & 46.6 & 24.0 \\
\hline Household size & 2.56 & 3.15 \\
\hline Number of children under 16 & 0.87 & 1.16 \\
\hline Obs (person-waves) & 23893 & 6945 \\
\hline
\end{tabular}

\section{Empirical Results}

\subsection{Simple Difference-in-differences Estimates without Controls}

Figures 1 and 2 suggest that it is perhaps no coincidence that immigrants in Germany decrease their levels of savings and remittances while increasing loan repayments (hence increasing consumption of durable goods) as Germany is undergoing a landmark reform of its immigration law. This is consistent with our theoretical model as the precautionary savings motive arising from the uncertainties, here due to their legal status, will be much weakened for immigrants as a result of the reform. 
Table 2 presents simple difference-in-differences estimates without any further controls. The natives are used as controls while immigrants form the treatment group. We simply split the sample into two halves, with pre-treatment years defined as 1998-2001 inclusive ${ }^{6}$.

While natives, as expected, have significantly higher net income than immigrants on average, both natives and immigrants have experienced a 10.5\% increase in household net income over the sample period. However the similarity ends when it comes to savings. It turns out that there is virtually no change in savings, loan repayments or remittances over the sample period for natives. ${ }^{7}$ In contrast, savings and remittances go down while loan repayments go up for immigrants. The patterns are consistent with the figures in the previous section and the changes are all statistically significant at the 5\% level.

However, the difference-in-differences estimates are only statistically significant for savings and remittances. This suggests the introduction of the new citizenship law in 2000 causes a statistically significant decrease in both savings and remittances relative to what it would have been in the absence of the reform. The decreases are also economically significant, at €20/month for savings and €11/month for remittances respectively. This corresponds to a $13 \%$ drop in savings and a remarkable $29 \%$ decrease in remittances compared to the base period. On the other hand, there appears to be no effect on loan repayments or adjustment household net income. These results are

\footnotetext{
${ }^{6}$ Assigning 2000 and 2001 to the pre-treatment years allows for lags in the naturalization process (often taking more than 1 year) as well as doubling the sample size. On the other hand, immigrants' behaviour might have already changed during this transition period due to expectations.

7 Our sample of "natives" (recall they were born in Germany and are currently German nationals) inevitably includes a very small number of second-generation immigrants. It should not be surprising that a very small percentage of natives do report positive remittances. If anything, this measurement problem will work against us in finding statistically significant effects.
} 
consistent with the view that the relaxation of immigration control in general and the easing of the requirements for naturalization in particular have significantly weakened precautionary savings for immigrants. In other words, a change in the legal status in favour of the immigrants reduces the level of uncertainty which in turn changes their savings behaviour.

Table 2: Simple Difference-in-differences Estimates Without Controls

\begin{tabular}{|l|c|c|c|c|c|c|c|}
\hline & \multicolumn{3}{|c|}{ Natives } & \multicolumn{3}{c|}{ Immigrants } & $\begin{array}{c}\text { Difference- } \\
\text { in- } \\
\text { differences }\end{array}$ \\
\hline & $1998-$ & $2002-$ & Difference & $\begin{array}{c}1998- \\
2001\end{array}$ & $\begin{array}{c}2002- \\
2005\end{array}$ & Difference & \\
\hline Savings & 2001 & 2005 & & 152.97 & 136.37 & $\mathbf{- 1 6 . 6 0}$ & $\mathbf{- 2 0 . 1 4}$ \\
& $(3.22)$ & $(3.58)$ & $(4.80)$ & $(5.01)$ & $(5.32)$ & $(7.35)$ & $(9.78)$ \\
\hline Loan & 85.04 & 87.72 & 2.68 & 87.69 & 99.40 & $\mathbf{1 1 . 7 4}$ & 9.04 \\
Repayments & $(2.38)$ & $(2.44)$ & $(3.42)$ & $(3.75)$ & $(4.07)$ & $\mathbf{( 5 . 5 6 )}$ & $\mathbf{( 7 . 0 3 )}$ \\
\hline Remittances & 3.35 & 3.19 & -0.16 & 38.15 & 27.02 & $\mathbf{- 1 1 . 1 4}$ & $\mathbf{- 1 0 . 9 8}$ \\
& $(0.40)$ & $(0.43)$ & $(0.59)$ & $(2.17)$ & $(1.81)$ & $(2.92)$ & $(1.92)$ \\
\hline Net Income & 2400.53 & 2652.55 & $\mathbf{2 5 2 . 0 1}$ & 2126.55 & 2349.55 & $\mathbf{2 2 3 . 0 0}$ & -29.01 \\
& $(12.09)$ & $(14.90)$ & $(19.02)$ & $(18.12)$ & $(21.79)$ & $(28.11)$ & $(38.52)$ \\
\hline Observations & 12,639 & 11,254 & & 3,866 & 3,079 & & \\
\hline
\end{tabular}

Notes: Standard errors in parenthesis. Bold difference estimates indicate statistical significance at the 5\% level.

\subsection{Difference-in-differences Estimates with Controls}

The difference-in-differences estimates presented in Table 2 do not control for individual and household characteristics. Table 3 shows difference-in-differences estimates with a full set of controls for age, gender, education, labour market status, benefit status, house ownership, ethnic origin, and number of people and dependent children in the household. It is clear that adding all these controls do not change the 
results in Table 2 at all. If anything, the size of reductions of savings is now even higher, at €30/month.

Table 3: Difference-in-differences Estimates with Controls

\begin{tabular}{|c|c|c|c|c|}
\hline & Savings & $\begin{array}{c}\text { Loan } \\
\text { Repayments }\end{array}$ & Remittances & $\begin{array}{l}\text { Household } \\
\text { Net Income }\end{array}$ \\
\hline Immigrant & $\begin{array}{c}-10.023 \\
(10.825)\end{array}$ & $\begin{array}{r}\mathbf{- 1 8 . 4 7 7} \\
(6.384)\end{array}$ & $\begin{array}{l}22.741 \\
(3.465)\end{array}$ & $\begin{array}{l}-210.043 \\
(38.835)\end{array}$ \\
\hline Post 2002 & $\begin{array}{l}-2.635 \\
(4.508)\end{array}$ & $\begin{array}{c}3.112 \\
(3.715)\end{array}$ & $\begin{array}{c}-0.569 \\
(0.669)\end{array}$ & $\begin{array}{l}\mathbf{2 0 3 . 8 7 3} \\
(16.622)\end{array}$ \\
\hline Immigrant*Post 2002 (DiD) & $\begin{array}{l}-30.711 \\
(8.591) \\
\end{array}$ & $\begin{array}{r}12.278 \\
(6.545) \\
\end{array}$ & $\begin{array}{l}\mathbf{- 1 1 . 2 6 1} \\
(2.892) \\
\end{array}$ & $\begin{array}{l}-33.445 \\
(30.680)\end{array}$ \\
\hline Age & $\begin{array}{l}-2.340 \\
(2.210)\end{array}$ & $\begin{array}{c}7.132 \\
(1.311) \\
\end{array}$ & $\begin{array}{c}-0.260 \\
(0.390)\end{array}$ & $\begin{array}{l}\mathbf{4 2 . 8 2 8} \\
(8.372) \\
\end{array}$ \\
\hline Age square & $\begin{array}{c}0.043 \\
(0.026) \\
\end{array}$ & $\begin{array}{c}\mathbf{- 0 . 0 8 9} \\
(0.015) \\
\end{array}$ & $\begin{array}{c}0.007 \\
(0.005) \\
\end{array}$ & $\begin{array}{c}\mathbf{- 0 . 3 0 9} \\
(0.098) \\
\end{array}$ \\
\hline Female & $\begin{array}{l}-24.783 \\
(7.784)\end{array}$ & $\begin{array}{l}-5.084 \\
(4.880)\end{array}$ & $\begin{array}{l}-0.500 \\
(1.115)\end{array}$ & $\begin{array}{l}-57.665 \\
(29.579)\end{array}$ \\
\hline Married & $\begin{array}{c}71.153 \\
(10.204) \\
\end{array}$ & $\begin{array}{l}12.246 \\
(6.345) \\
\end{array}$ & $\begin{array}{c}\mathbf{6 . 0 9 9} \\
(1.732) \\
\end{array}$ & $\begin{array}{l}\mathbf{2 8 3 . 6 5 3} \\
(37.744) \\
\end{array}$ \\
\hline Years of Education & $\begin{array}{l}26.624 \\
(1.937) \\
\end{array}$ & $\begin{array}{c}0.180 \\
(1.263) \\
\end{array}$ & $\begin{array}{c}\mathbf{1 . 3 7 9} \\
(0.315)\end{array}$ & $\begin{array}{c}\mathbf{1 2 7 . 2 8 6} \\
(6.672) \\
\end{array}$ \\
\hline Turkish & $\begin{array}{l}-12.203 \\
(13.561) \\
\end{array}$ & $\begin{array}{c}30.142 \\
(11.679)\end{array}$ & $\begin{array}{c}15.237 \\
(5.257)\end{array}$ & $\begin{array}{l}\mathbf{- 1 3 8 . 5 5 7} \\
(50.753) \\
\end{array}$ \\
\hline Former Yugoslavia & $\begin{array}{c}12.681 \\
(21.584)\end{array}$ & $\begin{array}{c}33.562 \\
(15.434)\end{array}$ & $\begin{array}{c}52.549 \\
(10.642) \\
\end{array}$ & $\begin{array}{c}93.881 \\
(61.844) \\
\end{array}$ \\
\hline Employed & $\begin{array}{l}\mathbf{6 1 . 3 5 3} \\
(8.777)\end{array}$ & $\begin{array}{l}28.738 \\
(4.572)\end{array}$ & $\begin{array}{c}4.842 \\
(1.499) \\
\end{array}$ & $\begin{array}{l}\mathbf{4 7 1 . 4 0 8} \\
(32.428)\end{array}$ \\
\hline Unemployed & $\begin{array}{l}-43.642 \\
(8.627)\end{array}$ & $\begin{array}{c}-\mathbf{- 1 3 . 1 2 4} \\
(5.478)\end{array}$ & $\begin{array}{c}2.374 \\
(3.845)\end{array}$ & $\begin{array}{l}-211.133 \\
(35.016)\end{array}$ \\
\hline Receiving Social Assistance & $\begin{array}{l}-33.574 \\
(8.330)\end{array}$ & $\begin{array}{c}-33.914 \\
(6.367)\end{array}$ & $\begin{array}{l}\mathbf{- 6 . 4 7 9} \\
(1.642)\end{array}$ & $\begin{array}{l}-297.156 \\
(41.587) \\
\end{array}$ \\
\hline Own House & $\begin{array}{l}78.975 \\
(8.340) \\
\end{array}$ & $\begin{array}{c}-7.761 \\
(5.343) \\
\end{array}$ & $\begin{array}{l}-3.166 \\
(1.565) \\
\end{array}$ & $\begin{array}{l}\mathbf{3 1 9 . 7 6 7} \\
(30.999) \\
\end{array}$ \\
\hline Household size & $\begin{array}{l}-1.032 \\
(4.368) \\
\end{array}$ & $\begin{array}{c}\mathbf{9 . 3 3 5} \\
(2.756) \\
\end{array}$ & $\begin{array}{l}-1.243 \\
(0.750)\end{array}$ & $\begin{array}{l}391.991 \\
(16.674)\end{array}$ \\
\hline Number of children under 16 & $\begin{array}{r}\mathbf{- 1 5 . 5 3 7} \\
(3.648) \\
\end{array}$ & $\begin{array}{c}-1.090 \\
(2.523) \\
\end{array}$ & $\begin{array}{c}0.497 \\
(0.760) \\
\end{array}$ & $\begin{array}{c}\mathbf{- 1 5 8 . 5 2 7} \\
(13.661) \\
\end{array}$ \\
\hline Constant & $\begin{array}{r}\mathbf{- 1 8 2 . 2 0 6} \\
(43.841) \\
\end{array}$ & $\begin{array}{c}\mathbf{- 9 0 . 8 0 9} \\
(28.674) \\
\end{array}$ & $\begin{array}{c}\mathbf{- 1 8 . 5 3 9} \\
(7.147) \\
\end{array}$ & $\begin{array}{r}\mathbf{- 1 8 6 3 . 5 8 1} \\
(165.028) \\
\end{array}$ \\
\hline Obs (person-waves) & 29856 & 29856 & 29856 & 29856 \\
\hline Adj-R ${ }^{2}$ & 0.099 & 0.017 & 0.055 & 0.333 \\
\hline
\end{tabular}

Notes: Standard errors in parenthesis. Bold difference estimates indicate statistical significance at the 5\% level. 


\subsection{Parametric Estimation}

It is worth noting that Table 3 does not control for variations in adjusted household net incomes in the estimation of the savings and remittances equations. Economists as well as policymakers are not only interested in (changes in) the absolute levels of savings and remittances, but also in the (changes in) the relative levels of savings, often measured as a share of net income. In particular, a measure of key importance is the marginal propensity to save (MPS), which refers to the increase in saving that results from a marginal increase in income.

Table 4 shows the random-effect Tobit estimates for the 3 alternative definitions of savings. In the following we will just focus on the change in the MPS differential between natives and immigrants arising from the introduction of the new citizenship law. The MPS for natives pre 2002 is in the range of $17.9 \%$ to $19.3 \%$ depending on which measure is used. The MPS for immigrants is almost $40 \%$ (around 7 percentage points) higher across all measures of savings in the base period, consistent with a much stronger motive for precautionary savings. There is a general decrease in MPS in the magnitude of 2 percentage points across both subsamples post 2002. However, the MPS for immigrants as a whole has suffered an additional large and statistically significant drop, in the range of 2.8 to 4.8 percentage points. Indeed, this implies that the MPS gap in favour of immigrants pre-reform was closed by at least $40 \%$ if the narrowest definition of savings is used. When loan repayments and remittances are treated as savings, the gap could be reduced by as much as $65 \%$. 
Table 4: Random-Effect TOBIT Estimates with Alternative Savings Measures

\begin{tabular}{|c|c|c|c|}
\hline & Saving0 & Saving1 & Saving2 \\
\hline Immigrant & $\begin{array}{c}\mathbf{- 1 8 0 . 7 7} \\
(26.15)\end{array}$ & $\begin{array}{c}-\mathbf{2 0 2 . 8 0} \\
(27.17)\end{array}$ & $\begin{array}{r}\mathbf{- 1 6 3 . 2 7} \\
(26.64)\end{array}$ \\
\hline Post 2002 & $\begin{array}{c}2.38 \\
(11.29) \\
\end{array}$ & $\begin{array}{c}-11.14 \\
(12.39)\end{array}$ & $\begin{array}{c}-12.59 \\
(12.41)\end{array}$ \\
\hline Net Income (MPS) & $\begin{array}{c}\mathbf{0 . 1 7 9} \\
(0.004) \\
\end{array}$ & $\begin{array}{c}\mathbf{0 . 1 9 3} \\
(0.004) \\
\end{array}$ & $\begin{array}{c}\mathbf{0 . 1 9 3} \\
(0.004) \\
\end{array}$ \\
\hline Immigrant * Post 2002 & $\begin{array}{c}9.64 \\
(27.98)\end{array}$ & $\begin{array}{c}\mathbf{8 4 . 2 3} \\
(29.87)\end{array}$ & $\begin{array}{c}\mathbf{5 8 . 3 1} \\
(29.36)\end{array}$ \\
\hline Immigrant $*$ Net Income & $\begin{array}{c}\mathbf{0 . 0 6 8} \\
(0.009)\end{array}$ & $\begin{array}{c}\mathbf{0 . 0 7 4} \\
(0.010)\end{array}$ & $\begin{array}{c}\mathbf{0 . 0 7 4} \\
(0.009)\end{array}$ \\
\hline Post $2002 *$ Net Income & $\begin{array}{c}\mathbf{- 0 . 0 2 0} \\
(0.004) \\
\end{array}$ & $\begin{array}{c}\mathbf{- 0 . 0 1 4} \\
(0.004) \\
\end{array}$ & $\begin{array}{c}\mathbf{- 0 . 0 1 4} \\
(0.004) \\
\end{array}$ \\
\hline Immigrant * Post $2002 *$ Net Income & $\begin{array}{c}\mathbf{- 0 . 0 2 8} \\
(0.010) \\
\end{array}$ & $\begin{array}{c}\mathbf{- 0 . 0 4 8} \\
(0.011) \\
\end{array}$ & $\begin{array}{c}\mathbf{- 0 . 0 4 3} \\
(0.011)\end{array}$ \\
\hline Age & $\begin{array}{c}\mathbf{- 1 4 . 6 6} \\
(2.96) \\
\end{array}$ & $\begin{array}{c}0.83 \\
(3.05) \\
\end{array}$ & $\begin{array}{c}1.60 \\
(3.07) \\
\end{array}$ \\
\hline Age square & $\begin{array}{c}\mathbf{0 . 1 6 9} \\
(0.033)\end{array}$ & $\begin{array}{l}-0.028 \\
(0.034)\end{array}$ & $\begin{array}{c}-0.031 \\
(0.035)\end{array}$ \\
\hline Female & $\begin{array}{c}-16.57 \\
(11.21)\end{array}$ & $\begin{array}{c}-19.61 \\
(11.10)\end{array}$ & $\begin{array}{l}-22.67 \\
(11.18) \\
\end{array}$ \\
\hline Married & $\begin{array}{c}\mathbf{1 0 4 . 3 7} \\
(10.41)\end{array}$ & $\begin{array}{c}\mathbf{9 5 . 1 7} \\
(10.82)\end{array}$ & $\begin{array}{c}98.35 \\
(10.86)\end{array}$ \\
\hline Years of Education & $\begin{array}{l}14.25 \\
(1.78)\end{array}$ & $\begin{array}{c}\mathbf{9 . 9 6} \\
(1.78) \\
\end{array}$ & $\begin{array}{l}\mathbf{1 1 . 6 9} \\
(1.78)\end{array}$ \\
\hline Turkish & $\begin{array}{c}-56.67 \\
(26.91)\end{array}$ & $\begin{array}{c}28.39 \\
(24.82)\end{array}$ & $\begin{array}{c}\mathbf{6 3 . 4 1} \\
(24.69)\end{array}$ \\
\hline Former Yugoslavia & $\begin{array}{c}17.05 \\
(30.20)\end{array}$ & $\begin{array}{c}40.45 \\
(30.07)\end{array}$ & $\begin{array}{c}113.92 \\
(28.99)\end{array}$ \\
\hline Employed & $\begin{array}{l}75.35 \\
(9.38) \\
\end{array}$ & $\begin{array}{l}75.46 \\
(9.95) \\
\end{array}$ & $\begin{array}{l}78.15 \\
(9.97) \\
\end{array}$ \\
\hline Unemployed & $\begin{array}{c}-78.36 \\
(15.26) \\
\end{array}$ & $\begin{array}{c}\mathbf{6 9 . 3 2} \\
(15.51) \\
\end{array}$ & $\begin{array}{c}-54.77 \\
(15.37) \\
\end{array}$ \\
\hline Receiving Social Assistance & $\begin{array}{c}\mathbf{- 1 1 4 . 4 9} \\
(22.51)\end{array}$ & $\begin{array}{c}\mathbf{- 1 0 1 . 9 1} \\
(21.67)\end{array}$ & $\begin{array}{r}\mathbf{- 1 0 1 . 8 7} \\
(21.51)\end{array}$ \\
\hline Own House & $\begin{array}{c}0.145 \\
(8.968) \\
\end{array}$ & $\begin{array}{l}-8.31 \\
(9.24) \\
\end{array}$ & $\begin{array}{c}-12.76 \\
(9.26) \\
\end{array}$ \\
\hline Household size & $\begin{array}{l}-72.84 \\
(4.62) \\
\end{array}$ & $\begin{array}{r}-\mathbf{6 5 . 7 3} \\
(4.79) \\
\end{array}$ & $\begin{array}{c}\mathbf{- 6 6 . 1 8} \\
(4.80) \\
\end{array}$ \\
\hline Number of children under 16 & $\begin{array}{c}3.163 \\
(3.346) \\
\end{array}$ & $\begin{array}{c}3.011 \\
(3.816)\end{array}$ & $\begin{array}{c}2.611 \\
(3.809)\end{array}$ \\
\hline Constant & $\begin{array}{c}\mathbf{- 1 6 1 . 7 8} \\
(61.08)\end{array}$ & $\begin{array}{c}-290.89 \\
(62.98)\end{array}$ & $\begin{array}{c}-335.13 \\
(63.31)\end{array}$ \\
\hline Obs (person-waves) & 29,856 & 29,856 & 29,856 \\
\hline Rho & 0.486 & 0.373 & 0.379 \\
\hline Log likelihood & -132898.13 & -161415.85 & -164367.81 \\
\hline
\end{tabular}

Notes: Standard errors in parenthesis. Bold cases indicate statistical significance at the 5\% level. Saving1 include loan repayments while saving2 include both loan repayments and remittances. 


\subsection{Sensitivity analysis}

We have carried out various robustness checks (not reported to save space) to make sure our findings are not sensitive with respect to functional forms (e.g. OLS vs TOBIT) or the treatment of the transition years. In the following we will focus on the validity of the natural experiment and test whether the causal effect indicated by the difference-in-difference model might be due to some remaining heterogeneity among immigrants. We simply split the immigrant sample into naturalized immigrants and foreigners according to their pre-reform citizenship status and repeat the difference-indifferences exercises using the same control group of natives. If the nationality law which was introduced in 2000 was found to affect savings and remittances behaviour for immigrants who had already acquired German citizenship by 1999, then the causal effects we have found in the previous sections will be questionable.

Table 5A shows that the 2000 reform has had no effect whatsoever on immigrants who had already been naturalized by the time of the reform. In contrast, Table 5B shows that our main findings hold when we compare the subsample of foreigners who did not have German citizenships by the time the law was changed to the same control group of natives, although the difference-in-difference estimate for savings was only statistically significant at the $25 \%$ level $^{8}$.

This exercise clearly demonstrates that the causal effect we have identified is not driven by some remaining heterogeneity between naturalized immigrants and foreigners and hence lends strong support to the validity of natural experiment.

\footnotetext{
${ }^{8}$ This might be due to a slight attrition bias introduced through the requirement that all immigrants must have their pre-reform legal status known.
} 
Table 5A: Simple Difference-in-differences Estimates Without Controls, Natives vs Naturalized Immigrants

\begin{tabular}{|l|c|c|c|c|c|c|c|}
\hline & \multicolumn{3}{|c|}{ Natives } & \multicolumn{2}{c|}{ Naturalized immigrants } & $\begin{array}{c}\text { Difference- } \\
\text { in- } \\
\text { differences }\end{array}$ \\
\hline & $1998-$ & $2002-$ & Difference & $\begin{array}{c}1998- \\
2001\end{array}$ & $\begin{array}{c}2002- \\
2005\end{array}$ & Difference & \\
& 2001 & 2005 & & 164.35 & 153.14 & -11.21 & -14.75 \\
Savings & 220.58 & 224.12 & 3.54 & $16.57)$ & $(16.57)$ \\
& $(3.22)$ & $(3.58)$ & $(4.80)$ & $(5.01)$ & $(5.32)$ & $(12.68)$ & 14.77 \\
Loan & 85.04 & 87.72 & 2.68 & 66.52 & 83.97 & $\mathbf{1 7 . 4 5}$ & $(11.71)$ \\
Repayments & $(2.38)$ & $(2.44)$ & $(3.42)$ & $(4.81)$ & $(6.32)$ & $(7.80)$ & 0.31. \\
\hline Remittances & 3.35 & 3.19 & -0.16 & 18.87 & 19.02 & 0.15 & $(2.16)$ \\
\hline Net Income & 2400.53 & 2652.55 & $\mathbf{2 5 2 . 0 1}$ & 2106.07 & 2413.49 & $\mathbf{3 0 7 . 4 2}$ & 55.41 \\
& $(12.09)$ & $(14.90)$ & $(19.02)$ & $(30.07)$ & $(41.65)$ & $(50.05)$ & $(65.60)$ \\
\hline Observations & 12,639 & 11,254 & & 1,256 & 909 & & \\
\hline
\end{tabular}

Notes: Standard errors in parenthesis. Bold difference estimates indicate statistical significance at the $5 \%$ level.

Table 5B: Simple Difference-in-differences Estimates Without Controls, Natives vs Foreigners

\begin{tabular}{|c|c|c|c|c|c|c|c|}
\hline & \multicolumn{3}{|c|}{ Natives } & \multicolumn{3}{|c|}{ Foreigners } & \multirow{2}{*}{$\begin{array}{l}\text { Difference- } \\
\text { in- } \\
\text { differences }\end{array}$} \\
\hline & $\begin{array}{l}1998- \\
2001\end{array}$ & $\begin{array}{l}2002- \\
2005\end{array}$ & Difference & $\begin{array}{l}1998- \\
2001\end{array}$ & $\begin{array}{l}2002- \\
2005\end{array}$ & Difference & \\
\hline Savings & $\begin{array}{c}220.58 \\
(3.22) \\
\end{array}$ & $\begin{array}{c}224.12 \\
(3.58) \\
\end{array}$ & $\begin{array}{c}3.54 \\
(4.80) \\
\end{array}$ & $\begin{array}{c}148.69 \\
(6.56) \\
\end{array}$ & $\begin{array}{l}138.06 \\
(7.16) \\
\end{array}$ & $\begin{array}{l}-10.62 \\
(9.87) \\
\end{array}$ & $\begin{array}{c}-14.17 \\
(12.22) \\
\end{array}$ \\
\hline $\begin{array}{l}\text { Loan } \\
\text { Repayments }\end{array}$ & $\begin{array}{l}85.04 \\
(2.38)\end{array}$ & $\begin{array}{l}87.72 \\
(2.44)\end{array}$ & $\begin{array}{c}2.68 \\
(3.42)\end{array}$ & $\begin{array}{l}94.90 \\
(4.32)\end{array}$ & $\begin{array}{l}108.09 \\
(5.77)\end{array}$ & $\begin{array}{l}13.19 \\
(7.07)\end{array}$ & $\begin{array}{l}10.51 \\
(8.70)\end{array}$ \\
\hline Remittances & $\begin{array}{c}3.35 \\
(0.40)\end{array}$ & $\begin{array}{c}3.19 \\
(0.43)\end{array}$ & $\begin{array}{l}-0.16 \\
(0.59)\end{array}$ & $\begin{array}{l}48.54 \\
(3.17)\end{array}$ & $\begin{array}{l}36.38 \\
(2.90)\end{array}$ & $\begin{array}{l}-12.17 \\
(4.50)\end{array}$ & $\begin{array}{l}-12.01 \\
(2.37)\end{array}$ \\
\hline Net Income & $\begin{array}{c}2400.53 \\
(12.09)\end{array}$ & $\begin{array}{c}2652.55 \\
(14.90)\end{array}$ & $\begin{array}{l}252.01 \\
(19.02)\end{array}$ & $\begin{array}{c}2141.37 \\
(21.60)\end{array}$ & $\begin{array}{c}2415.22 \\
(28.17)\end{array}$ & $\begin{array}{l}273.85 \\
(34.96) \\
\end{array}$ & $\begin{array}{l}-21.84 \\
(47.83) \\
\end{array}$ \\
\hline Observations & 12,639 & 11,254 & & 2,525 & 1,758 & & \\
\hline
\end{tabular}

Notes: Standard errors in parenthesis. Bold difference estimates indicate statistical significance at the $5 \%$ level. 


\section{Conclusions}

This paper analysed the savings behaviour of natives and immigrants in Germany using the German Socio-Economic Panel (GSEOP) data. We found that savings reported by natives are $50 \%$ higher than that by immigrants on average, and natives are $35 \%$ more likely to have positive savings than immigrants. However, the savings gap is largely reduced once we take loan repayments and remittances into account. Moreover, controlling for a full set of individual and family characteristics, we found that the marginal propensity to save for immigrants is actually about $40 \%$ higher than natives.

We then moved on to estimate the importance of precautionary savings using a natural experiment arising from a change in the nationality law in Germany in 2000. Using a difference-in-differences approach, we found that the easing of the requirements for naturalization has caused significant reductions of savings and remittances for immigrants as a whole, in the magnitude of $13 \%$ and $29 \%$ respectively, comparing to the pre-reform period. On the other hand, the change in legislation does not affect the differential between natives and immigrants in loan repayments or total net income. These results are also robust to adding controls for individual and household characteristics.

Our parametric specification also suggests that the introduction of the new nationality law reduces the gap between natives and immigrants in marginal propensity to save by $40 \%$ to $65 \%$, depending on the measure of savings used.

Our results are robust with respect to a number of sensitivity checks. In particular, we have shown that the 2000 reform has had no effect on immigrants who had already acquired German citizenship by the time the law was introduced. This exercise clearly 
demonstrates that the causal effect we have identified is not driven by some remaining heterogeneity between naturalized immigrants and foreigners and hence lends strong support to the validity of natural experiment. Put together, our findings suggest that much of the differences in terms of the savings behaviour between natives and immigrants are driven by the precautionary savings arising from the uncertainties about future income and legal status rather than cultural differences. 


\section{References}

Amuedo-Dorantes, C. and S. Pozo (2002), "Precautionary Saving by Young Immigrants and Young Natives”, Southern Economic Journal, vol. 29(1), pp 48-71.

Amuedo-Dorantes, C. and S. Pozo (2006), "Remittances as Insurance: Evidence from Mexican Immigrants”, Journal of Population Economics, vol. 19, pp 227-254.

Bauer, T.K. and M. Sinning (2005), "The Savings Behavior of Temporary and Permanent Migrants in Germany”, RWI Discussion Paper No. 29.

Borjas, G. (1987), "Self-selection and the Earnings of Immigrants", American Economic Review, 77(4), pp 531-553.

Carroll, C.D., Rhee, C. and B. Rhee, 1994, “Are There Cultural Effects on Saving? Some Cross-Sectional Evidence”, Quarterly Journal of Economics, vol. 109, 3, pp 685-700.

Chiswick, B., 1978, "The Effect of Americanization on the Earnings of Foreign-born Men”, Journal of Political Economy, vol. 86, 897-921.

Dustmann, C (1997), "Return Migration, Uncertainty and Precautionary Savings" , Journal of Development Economics, vol. 52, pp 295-316.

Dynan, K. E., Skinner, J. and S. P. Zeldes (2004), “Do the Rich Save More?”, Journal of Political Economy, vol. 112, pp 397-444.

Galor, O and O. Stark (1990), "Migrants' Savings, the Probability of Return Migration and Migrants’ Performance”, International Economic Review, vol. 31, pp 463-467.

Merkle, L and K. Zimmermann (1992), “Savings, Remittances, and Return Migration”, Economic Letters 38: 77-81.

Shamsuddin, A.F.M and D.J. DeVortez (1998), "Wealth Accumulation of Canadian and Foreign-born Households", Review of Income and Wealth, 44(4), pp 515-533. 